\title{
PERLINDUGAN HUKUM TERHADAP KORBAN KEJAHATAN TINDAK PIDANA NARKOTIKA BERKAITAN DENGAN UNDANG-UNDANG NOMOR 35 TAHUN 2009 TENTANG NARKOTIKA
}

\section{LEGAL PROTECTION AGAINST VICTIMS OF CRIME OF NARCOTICS RELATED TO LAW NUMBER 35 YEAR 2009 REGARDING NARCOTICS}

\author{
Sandi Nugraha, Feny Windyastusti \\ Sekolah Tinggi Ilmu Hukum IBLAM \\ Kramat Raya No.25, Senen, Jakarta Pusat \\ sandinugraha10797@gmail.com, Feny@iblam.ac.id
}

$\begin{array}{ll}\text { Submission } & : \text { 17 Januari } 2022 \\ \text { Accepted } & : \text { 25 Januari } 2022 \\ \text { Publish } & : \text { 31 Januari } 2022\end{array}$

\begin{abstract}
Narcotics and psychotropics are drugs or materials that are useful in the fields of treatment, service, health, and scientific development, and on the other hand can cause very detrimental dependence if used without supervision, strict and careful supervision. Article 27 paragraph (1) of the 1945 Constitution affirms "All citizens have the same position in law and government and are obliged to uphold the law and government with no exceptions". The article shows that everyone has the right to recognition, guarantee of protection, and fair legal certainty as well as equal recognition before the law. The research method used is normative legal research with the sources of legal materials used are primary, secondary and tertiary legal materials. The technique of collecting legal materials uses a documentary study technique and the technique of analyzing legal materials used is a qualitative technique. The results of the study indicate that legal protection for victims of narcotics crime has not been implemented in the Perspective of Law Number 35 of 2009 concerning Narcotics, causing injustice and legal uncertainty and future criminal law policies in providing legal protection to victims of narcotics abusers must not only reform criminal law. material, but also reforming formal criminal law and criminal law enforcement.
\end{abstract}

Keywoards : Legal Protection, Crime, Victims, Narcotics Abuse

\begin{abstract}
Abstrak
Narkotika dan psikotropika merupakan obat atau bahan yang bermanfaat di bidang pengobatan, pelayanan, kesehatan, dan pengembangan ilmu pengetahuan, dan pada sisi lain dapat menimbulkan ketergantungan yang sangat merugikan apabila dipergunakan tanpa pengendalian, pengawasan yang ketat dan seksama. Dalam Pasal 27 ayat (1) Undang-Undang Dasar 1945 menegaskan "Segala warga
\end{abstract}


negara bersamaan kedudukannya di dalam hukum dan pemerintahan dan wajib menjunjung hukum dan pemerintahan itu dengan tidak ada kecualinya". Pasal tersebut menunjukkan bahwa setiap orang berhak atas pengakuan, jaminan perlindungan, dan kepastian hukum yang adil serta pengakuan yang sama dihadapan hukum. Metode penelitian yang digunakan adalah penelitian hukum normatif dengan sumber bahan hukum yang digunakan adalah bahan hukum primer, sekunder dan tersier. Teknik pengumpulan bahan hukum menggunakan teknik studi dokumenter dan teknik analisis bahan hukum yang digunakan adalah teknik kualitatif. Hasil penelitian menunjukkan bahwa perlindungan hukum terhadap korban tindak pidana narkotika dalam perspektif Undang-Undang Nomor 35 Tahun 2009 Tentang Narkotika belum diterapkan sehingga menimbulkan ketidakadilan dan ketidakpastian hukum dan kebijakan hukum pidana di masa yang akan datang dalam memberikan perlindungan hukum terhadap korban penyalahguna narkotika selayaknya tidak hanya melakukan pembaharuan terhadap hukum pidana materiil saja, tetapi juga pembaharuan terhadap hukum pidana formil dan hukum pelaksana pidana.

\section{Kata Kunci: Perlindungan Hukum, Tindak Pidana, Korban, Penyalahgunaan Narkotika}

\section{A. Pendahuluan}

Negara Kesatuan Republik Indonesia adalah negara yang berdasar atas hukum (rechtsstaat) dan bukan negara atas kekuasaan (machtsstaat), maka kedudukan hukum harus ditempatkan di atas segala-galanya. Setiap perbuatan harus sesuai dengan aturan hukum tanpa kecuali. Hukum seringkali dipahami oleh masyarakat sebagai suatu perangkat aturan yang dibuat negara dan mengikat warga negaranya dengan mekanisme keberadaan sanksi sebagai pemaksa untuk menegakkan hukumnya. Negara mempunyai hak untuk memaksa diberlakukanya sanksi terhadap perbuatan yang melanggar hukum dimana pelakunya dinyatakan salah oleh keputusan pengadilan yang mempunyai kekuatan hukum tetap. ${ }^{1}$

Apabila ditinjau dari aspek fungsinya, salah satu ruang lingkup hukum publik dapat dibagi menjadi hukum pidana materiil dan hukum pidana formil. Pada dimensi hukum publik tersebut terdapat hubungan erat, mesra, dan tidak terpisahkan antara ketentuan hukum pidana materiil dan hukum pidana formal. Secara teoritis, normatif dan praktik ketentuan hukum pidana baik dari perpektif hukum pidana materiil dan hukum pidana formal tersebut bermuara kepada

\footnotetext{
${ }^{1}$ Teguh Prasetyo, Kriminalisasi Dalam Hukum Pidana, Nusa Media, Bandung, 2010, hlm.
} 
dimensi sistem peradilan pidana (SPP). Tegasnya, dimensi konteks tersebut tidak akan menjadi bermanfaat tanpa adanya sistem peradilan pidana (SPP) karena pada sistem peradilan pidana (SPP) itulah suatu ketentuan hukum pidana yang bersifat normatif diejawantahkan, ditransformasikan, dan diterapkan pada peraturan konkret melalui sistem peradilan pidana indonesia. ${ }^{2}$

Sebagai suatu sistem, sistem peradilan pidana mempunyai komponenkomponen penyelenggara, antara lain Kepolisian, Kejaksaan, Pengadilan dan Lembaga Pemasyarakatan yang semuanya akan saling terkait dan diharapkan adanya suatu kerja sama yang terintegrasi. Jika terdapat kelemahan pada salah satu sistem kerja komponennya, akan mempengaruhi komponen lainnya dalam sistem yang terintegrasi itu. Sistem peradilan pidana dapat dilihat dari berbagai perspektif, antara lain polisi, jaksa, hakim, tersangka/terdakwa, dan korban kejahatan. Diantara perspektif tersebut, perspektif korban kejahatan akan membawa pada kecerahan sekaligus sebagai penyempurna dari perspektif lainnya yang dijadikan acuan dalam penyelenggaraan peradilan pidana sekarang ini. Sistem peradilan harus melindungi semua orang dan keadilan ditujukan kepada orang yang terlanggar haknya dan orang yang disangka melanggar hukum pidana harus diperlakukan secara adil. ${ }^{3}$

Peradilan selama ini lebih mengutamakan perlindungan kepentingan pembuat kejahatan (offender centered), dilatarbelakangi oleh pandangan bahwa sistem peradilan pidana diselenggarakan untuk mengadili tersangka dan bukan untuk melayani kepentingan korban kejahatan. Alasan lain yang mendukung pandangan tersebut antara lain kejahatan adalah melanggar kepentingan publik, maka reaksi terhadap kejahatan menjadi monopoli negara sebagai representasi publik atau masyarakat. Pandangan tersebut mendominasi praktik peradilan pidana, akibatnya orang yang melanggar haknya dan menderita akibat kejahatan diabaikan oleh sistem peradilan pidana. ${ }^{4}$ Sebagaimana yang telah diuraikan di atas bahwa negara mempunyai hak untuk memaksa diberlakukanya sanksi terhadap perbuatan yang melanggar hukum. Dalam hal ini, salah satu perbuatan melanggar hukum yang dimaksud adalah penyalahgunaan narkotika.

\footnotetext{
${ }^{2}$ Lilik Mulyadi, Bunga Rampai Hukum Acara Pidana, PT. Alumni, Bandung, 2012, hlm. 4

${ }^{3}$ Ibid, hlm. 5

${ }^{4}$ Teguh Prsetyo, Op.cit, hlm. 117
} 
Narkotika dan psikotropika merupakan obat atau bahan yang bermanfaat di bidang pengobatan, pelayanan, kesehatan, dan pengembangan ilmu pengetahuan, dan pada sisi lain dapat menimbulkan ketergantungan yang sangat merugikan apabila dipergunakan tanpa pengendalian, pengawasan yang ketat dan seksama. Zat-zat narkotika yang semula ditunjukkan untuk kepentingan pengobatan, namun pada perkembangan ilmu pengetahuan dan teknologi, jenis-jenis narkotika dapat diolah sedemikian banyak serta dapat pula disalahgunakan fungsinya. ${ }^{5}$

Penyalahgunaan narkotika di berbagai lapisan dan kalangan masyarakat semakin meningkat, hal itu disebabkan Negara Indonesia memiliki wilayah yang begitu luas dan hal ini dimanfaatkan oleh sindikat menjadi peluang penyebaran narkotika. Dan hal lain lagi karena Indonesia telah terpengaruh oleh globalisasi sehingga memudahkan masyarakat mendapatkan narkotika dan kemudian menyalahgunakan narkotika tersebut. Penyalahgunaan narkotika di lingkungan masyarakat telah mengkhawatirkan dikarenakan dengan banyaknya peredaran narkotika ilegal dengan berbagai macam jenis. ${ }^{6}$

Untuk mengurangi terjadinya korban penyalahgunaan narkotika, keikutsertaan peranan semua pihak sangat diperlukan, lingkungan di rumah, di sekolah maupun di lingkungan masyarakat. Korban penyalahgunaan narkotika tidak dapat diberantas, tetapi bisa diminimalisir melalui lingkungan terdekat yaitu keluarga, sekolah, dan masyarakat. Penyalahgunaan narkotika menjadi ancaman serius bagi generasi muda karena kejahatan narkotika memiliki dampak yang luar biasa bagi generasi penerus bangsa. Penyalahgunaan narkotika tidak dapat dibiarkan terus bertambah karena semakin bertambahnya penyalahgunaan narkotika secara langsung tidak hanya merusak kesehatan fisik dan psikis (mental) para pemakainya, tetapi juga memiliki dampak lain yaitu melambatnya

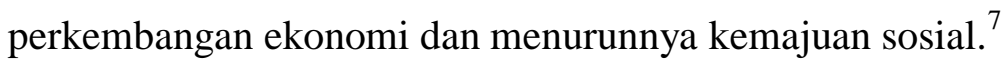

Seperti yang telah disebutkan bahwa Negara Indonesiaa adalah negara hukum, hal terpenting dalam negara hukum adalah adanya penghargaan dan komitmen menjunjung tinggi hak asasi manusia serta jaminan semua warga

\footnotetext{
${ }^{5}$ Muhammad Yamin, Tindak Pidana Khusus, Pustaka Setia, Bandung, 2012, hlm. 163.

6 Moh. Makaro Taufik, Suhasril, dan Moh. Zakky, Tindak Pidana Narkotika, Ghalia Indonesia, Bogor, 2005, hlm. 19 2018, hlm. 1

${ }^{7}$ Bambang Waluyo, Viktimologi Perlindungan Korban dan Saksi, Sinar Grafika, Jakarta,
} 
negara bersamaan kedudukannya di dalam hukum (equality of law). ${ }^{8}$ Dalam Pasal 27 ayat (1) Undang-Undang Dasar 1945 menegaskan "Segala warga negara bersamaan kedudukannya di dalam hukum dan pemerintahan dan wajib menjunjung hukum dan pemerintahan itu dengan tidak ada kecualinya". Berdasarkan Pasal tersebut dapat disimpulkan bahwa setiap orang berhak atas pengakuan, jaminan perlindungan, dan kepastian hukum yang adil serta pengakuan yang sama dihadapan hukum.

Pada praktiknya, masih dirasakan adanya ketidakseimbangan dalam politik penegakan hukum di Indonesia, terutama dalam hal perlakuan terhadap pelaku dan korban tindak pidana. Di dalam proses peradilan pidana semestinya banyak pihak yang harus dilindungi kepentingannya, baik kepentingan pelaku tindak pidana, kepentingan masyarakat dan/atau negara, maupun kepentingan korban. Adanya ketidakseimbangan dalam perlindungan kepentingan masing-masing dikhawatirkan tujuan hukum, yaitu mendatangkan tata tertib dan kedamaian dalam masyarakat serta terselesaikannya konflik menjadi semakin jauh.

Berdasarkan latar belakang permasalahan di atas, maka permasalahan dalam penelitian ini bagaimana perlindungan hukum korban tindak pidana narkotika dalam perspektif Undang-Undang Nomor 35 Tahun 2009 Tentang Narkotika? Serta bagaimana kebijakan hukum pidana di masa yang akan datang dalam memberikan perlindungan hukum terhadap korban penyalahguna narkotika?

\section{B. Hasil Penelitian dan Pembahasan}

Dalam penelitian ini, jenis penelitian yang digunakan adalah penelitian hukum normatif yaitu suatu jenis penelitian yang dilakukan dengan cara meneliti bahan pustaka atau data sekunder. ${ }^{9}$ Sumber bahan hukum yang digunakan mencakup bahan hukum primer, sekunder dan tersier. Bahan hukum primer berasal dari KUHP, Undang-Undang Nomor 35 Tahun 2009 tentang Narkotika, Undang-Undang Nomor 13 Tahun 2006 tentang Perlindungan Saksi dan Korban, serta peraturan perundang-undangan lainnya yang mempunyai kaitan dengan peneltian ini. Bahan hukum sekunder meliputi naskah akademik, rancangan

\footnotetext{
${ }^{8}$ Ibid, hlm. 2

9 Soerjono Soekanto and Sri Mamudji, Penelitian Hukum Normatif: Suatu Tinjauan Singkat, Rajagrafindo Perkasa, Jakarta, 2007, hlm. 13.
} 
undang-undang, hasil penelitian ahli hukum, buku ilmu hukum, dan lain-lain. Serta bahan hukum tersier meliputi kamus hukum, dan ensiklopedia Indonesia. Teknik pengumpulan bahan hukum menggunakan teknik studi dokumenter. Studi dokumenter merupakan studi yang mengkaji tentang berbagai dokumen, baik yang berkaitan dengan peraturan perundang-undangan maupun dokumendokumen yang sudah ada. Sementara teknik analisis bahan hukum yang digunakan adalah teknik kualitatif yaitu dengan cara menguraikan data secara bermutu dalam bentuk kalimat yang teratur, runtun, logis, tidak tumpang tindih, dan efektif, sehingga memudahkan untuk menginterpretasi data dan pemahaman hasil analisis, kemudian hasilnya dimanfaatkan untuk membahas permasalahan.

\section{Perlindungan Hukum Korban Tindak Pidana Narkotika Dalam} Perspektif Undang-Undang Nomor 35 Tahun 2009 Tentang Narkotika

Kebijakan perubahan Undang-Undang Nomor 22 Tahun 1997 menjadi Undang-Undang Nomor 35 Tahun 2009 tentang Nakotika adalah untuk meningkatkan kegiatan guna mencegah dan memberantas penyalahgunaan dan peredaran gelap narkotika yang sangat meruugikan dan membahayakan kehidupan masyarakat, bangsa, dan negara. Undang-Undang baru ini bertujuan untuk mengatur upaya pemberantasan terhadap tindak pidana narkotika melalui ancaman sanksi pidana. Peningkatan peredaran gelap narkotika dan psikotropika tidak terlepas dari kegiatan organisasi-organisasi kejahatan transnasional yang beroperasi di berbagai negara dalam suatu jaringan kejahatan internasional. Hal itu dilakukan karena keuntungan yang diperoleh sangat besar, organisasi kejahatan tersebut berusaha dengan segala cara untuk mempertahankan dan mengembangkan terus usaha peredaran gelap narkotika dan psikotropika. ${ }^{10}$

Penyalahgunaan narkotika dan obat-obat berbahaya di Indonesia beberapa tahun terakhir ini menjadi masalah serius dan telah mencapai masalah keadaan yang memperihatinkan sehingga menjadi masalah nasional. Korban penyalahgunaan narkoba telah meluas sedemikian rupa sehi ngga melampaui batas-batas strata sosial, umur, jenis kelamin. Merambah tidak hanya perkotaan

${ }^{10}$ Hari Sasangka, Narkotika dan Psikotropika Dalam Hukum Pidana Untuk mahasiswa dan Praktisi Serta Penyuluh Narkoba, Mandar Maju, Bandung, 2003, hlm. 35. 
tetapi merambah sampai pedesaan dan melampaui batas negara yang akibatnya sangat merugikan perorangan, masyarakat, negara, khususnya generasi muda. Bahkan dapat menimbulkan bahaya lebih besar lagi bagi kehidupan dan nilai-nilai budaya bangsa yang pada akhirnya dapat melemahkan ketahanan nasional. ${ }^{11}$

Merujuk kepada Konvensi Perserikatan Bangsa-Bangsa tentang pemberantasan peredaran gelap narkotika dan psikotropika, 1988 (United Nations Conventions Against Illicit Traffic in Narcotoc Drugs and Psychotropic Substances 1988). Konvensi Perserikatan Bangsa-Bangsa tentang pemberantsan peredaran gelap narkotika dan psikotropika, 1988 dimana telah disahkan oleh pemerintah Republik Indonesia berdasarkan Undang-Undang Republik Indonesia Nomor 7 Tahun 1997 bahwa Pemerintah Republik Indonesia memandang perlu untuk bersama-sama denngan anggota masyarakat dunia lainnya aktif mengambil bagian dalaam upaya memerantas peredaran gelap narkotika dan psikotropika. ${ }^{12}$

Undang-Undang Nomor 35 Tahun 2009 Tentang Narkotika, disamping dengan pendekatan hukum pidana dalam penegakan hukum terhadap penyalahgunaan dan peredaran gelap narkotika, juga dengan pendekatan hukum administrasi negara untuk pengaturan tentang pengadaan dan peredaran narkotika yang dalam perkembagannya pihak pemerintah mulai menata masyarakat dengan menggunakan sarana hukum. Penerapan pasal-pasal tindak pidana dalam UndangUndang Nomor 35 Tahun 2009 tentang Narkotika menganut ajaran asas legalitas ini sering dirujuk sebagai nullum delictum, nulla poena sine praevia lege poenali, artinya tidak ada delik, tidak ada pidana, tanpa didahului oleh ketentuan pidana dalam perundang-undangan. ${ }^{13}$

Korban menurut Undang-Undang Nomor 13 Tahun 2006 tentang Perlindungan Saksi dan Korban menyatakan korban adalah seseorang yang mengalami penderitaan fisik, mental, dan/atau kerugian ekonomi yang diakibatkan oleh suatu tindak pidana. Dalam upaya memberantas lalu lintas peredaran narkotika dan psikotropika di indonesia, pemerintah mengeluarkan beberapa Undang-Undang dan beberapa peraturan yang dikeluarkan oleh menteri kesehatan, dengan mengacu kepada hasil konvensi PBB tahun 1971 dan tahun

\footnotetext{
${ }^{11}$ Ibid, hlm. 37

${ }^{12}$ Soedjono Dirdjosisworo, Narkotika dan Remaja, Alumni, Bandung, 1977, hlm. 35.

${ }^{13}$ Bambang Waluyo, Op.cit, hlm. 45
} 
1988 tentang pemberantassan lalu lintas peredaran narkotika dan psikotropika.

Salah satu peraturan yang telah dikeluarkan adalah Undang-Undang Nomor 35 Tahun 2009 tentang Narkotika. ${ }^{14}$

Peredaran gelap narkotika membawa dampak menimbulkan korban penyalagunaan narkotika yang semakin hari semakin meningkat jumlahnya. Hal yang menarik jika dipehartikan bunyi Pasal 127 Undang-Undang Nomor 35 Tahun 2009 Tentang Narkotika belum terdapat perindungan hukum terhadap korban tindak pidana narkotika, justru korban dalam tindak pidana narkotika disamakan dengan pengedar maupun bandar narkotika. Bunyi Pasal 127 UndangUndang Nomor 35 Tahun 2009 Tentang Narkotika sebagai berikut:

(1). Setiap Penyalah Guna:

a. Narkotika Golongan I bagi diri sendiri dipidana dengan pidana penjara paling lama 4 (empat) tahun;

b. Narkotika Golongan II bagi diri sendiri dipidana dengan pidana penjara paling lama 2 (dua) tahun; dan

c. Narkotika Golongan III bagi diri sendiri dipidana dengan pidana penjara paling lama 1 (satu) tahun.

(2). Dalam memutus perkara sebagaimana dimaksud pada ayat (1), hakim wajib memperhatikan ketentuan sebagaimana dimaksud dalam Pasal 54, Pasal 55, dan Pasal 103.

(3). Dalam hal Penyalah Guna sebagaimana dimaksud pada ayat (1) dapat dibuktikan atau terbukti sebagai korban penyalahgunaan Narkotika, Penyalah Guna tersebut wajib menjalani rehabilitasi medis dan rehabilitasi sosial.

Dilain pihak Undang-Undang Nomor 35 Tahun 2009 tentang Narkotika, tujuan yang hendak dicapai dengan pemberlakuan Undang-Undang ini adalah terdapat di dalam Pasal 4 Undang-Undang Nomor 35 Tahun 2009 Tentang Narkotika yang berbunyi supaya menjamin pengaturan upaya rehabilitasi medis dan rehabilitasi sosial bagi penyalah guna dan pecandu narkotika. Tetapi fakta dilapanga yang terjadi saat ini para korban tindak pidana pidana narkotika dijatuhi hukuman penjara. Artinya para penyalahguna narkotika penyalahguna dikonstruksi dengan pasal di luar pasal pengguna (Pasal 127) yang berorientasi pada bukan tindakan rehabilitasi. Pandangan yang berlaku di dalam masyarakat bahwa penyalahguna narkotika ataupun pecandu narkotika adalah pelanggar hukum, pandangan tersebut benar adanya namun yang perlu diketahui bahwa

\footnotetext{
${ }^{14}$ Ibid, hlm. 32
} 
mereka bukanlah penjahat, tetapi mereka adalah korban dari bujuk rayu dari para pengedar narkotika maupun bandar narkotika. Sifat adiktif yang terkandung di dalam narkotika membuat para penyalahguna dan pecandu narkotika ketergantungan untuk mengkonsumsi narkotika. ${ }^{15}$

Penegakan hukum terhadap kejahatan di Indonesia, khusus dalam pemidanaan, seharusnya merujuk pada pendekatan norma yang bersifat menghukum penjahat sehingga dapat membuat efek jera. Eksistensi penegakan hukum dalam hal visi dan misi penegakan hukumanya, baik ditingkat penyidikan, penuntutan sampai ketingkat peradilan, seharusnya memiliki presepsi yang sama sesuai tuntutan hukum dan keadilan masyarakat. Pada kenyataan eksistensi aparat penegak hukum tersebut terdapat kecendrungan atau terkesan membela matimatian pelaku kejahatan dan kurang memperhatikan banyaknya korban yang telah berjatuhan sebagai dampak dari ketergantungan narkotika. ${ }^{16}$

2. Kebijakan Hukum Pidana di Masa yang Akan Datang Dalam Memberikan Perlindungan Hukum Terhadap Korban Penyalahguna Narkotika

Pada saat hukum dikonsepkan sebagai suatu sistem, hukum akan menuju pada suatu proses demi tegaknya hukum itu sendiri. Proses untuk dapat terwujudnya Indonesia baru adalah merupakan suatu proses politik yang disadari. Proses pembaharuan ini dikenal dengan istilah Legal Reform. Proses ini adalah bagian dari proses politik yang progresif dan refoematif. Di sini lah hukum dapat difungsikan sebagai tool of social engineering. ${ }^{17}$

Dalam fungsinya yang reformatif sebagai tool of social engineering, di Indonesia pembaharuan hukum konsepnya yang terbatas legal reform (pembaharuan Undang-Undang atau pembaharuan sistem perundang-undangan belaka). Soetandyo menjelaskan di Indonesia pembaharuan hukum sebagai legal reform dalam realitas sejarahnya belum pernah mendapatkan keberhasilan. Reform atau pembaharuan seperti ini hanya berkecenderungan untuk membatasi

\footnotetext{
${ }^{15}$ Parasian Simanungkalit, Model Pemidanaan Yang Ideal Bagi Korban Pengguna Narkoba Di Indonesia, Yustisia, Surakarta, 2013, hlm. 80.

${ }^{16}$ Siswanto Sunarsono, Penegakan Hukum Psikotropika Dalam Kajian Sosiologi Hukum, Grafindo, Jakarta, 2004, hlm. 7

${ }^{17}$ Yesmil Anwar \& Adang, Pembaharuan Hukum Pidana, PT. Grasindo, Jakarta, 2008, hlm. 2
} 
diri pada pembaharuan Undang-Undang atau pasal dan ayat yang telah ada dalam perundangundangan saja, dan tidak mempertanyakan paradigma ideologisnya. ${ }^{18}$

Pada asasnya, secara konkret pembaharuan hukum pidana harus meliputi pembaharuan hukum pidana materiil, huum pidana formal dan hukum pelaksanaan pidana. ketiga idang hukum tersebut bersama-sama atau secara integral diperbaiki agar tidak terdapat kendala dalam pelaksanaannya. Menurut Barda Nawawi Arief makna dan hakikat pembaharuan hukum pidana materiil adalah sebagai berikut: ${ }^{19}$

a. Dilihat dari sudut pendekatan kebijakan

1) Sebagai bagian dari kebijakan sosial, pembaharuan hukum pidana pada hakikatnya bagian dari upaya untuk mengatasi masalah-masalah sosial (termasuk masalah kemanusiaan) dalam rangka mencapai/menunjang tujuan nasional (kesejahteraan masyarakat dan selanjutnya).

2) Sebagai bagian dari kebijakan kriminal, pembaharuan hukum pidana pada hakikatnya bagian dari upaya perlindungan masyarakat (khususnya upaya penanggulangan kejahatan).

3) Sebagai bagian dari kebijakan penegakan hukum, pembaharuan hukum pidana pada hakikatnya bagian dari upaya pembaharuan substansial hukum (legal substance) dalam rangka lebih mengefektifkan penegakan hukum.

b. Dilihat dari sudut pendekatan nilai

Pembaharuan hukum pidana pada hakikatnya merupakan upaya melakukan peninjauan dan penilaian kembali nilai-nilai sosio-politik, sosiofilosofis dan sosio-kultural yang melandasi dan memberi isi terhadap muatan normatif dan substantif hukum pidana, apabila orientasi nilai dari hukum pidana yang dicita-citakan. Dengan dimensi dan optik demikian, pada asassnya secara konkret memang diperlukan pembaharuan dibidang hukum pidana memang mutlak diperlukan, sudah merupakan sebuah keharusan yang tidak dapat ditunda dan dielakkan lagi eksistensinya.

18 Soetandyo Wignjosoebroto, Hukum:Paradigma, Metode dan Dimanika Masalahnya. Elsamhuma, Jakarta, 2002, hlm. 356

${ }^{19}$ Barda Nawawi Arief, Beberapa Aspek Kebijakan Penegakan dan Pengembangan Hukum Pidana, PT. Citra Aditya Bakti, Bandung, 2005, hlm. 31-32. 
Kebijakan hukum pidana pada hakikaatnya merupakan usaha untuk mewujudkan peraturan perundang-undangan pidana agar sesuai denagn keadaan pada waktu tertentu (ius constitutum) dan masa mendatang (ius constituendum). Kebijakan hukum pidana identik dengan penal reform dalam arti sempit, karena sebagai suatu sistem hukum pidana terdiri dari budaya (cultural), struktur (structural), dan substansi (substansive) hukum. Karena perundang-undangan merupakan bagian dari substansi hukum, pembaharuan hukum pidana disamping memperbaharui perundang-undangan juga mencakup pembaharuan ide dasar dan ilmu hukum pidana. ${ }^{20}$

Usaha dan kebijakan untuk membuat peraturan hukum pidana yang baik pada hakikatnya tidak dapat dilepaskan dari tujuan penanggulangan kejahatan. Kebijakan atau politik hukum pidana merupakan bagian dari politik kriminal (criminal policy), politik hukum pidana identik dengan penanngulangan kejahatan. Digunakannya hukum pidana di Indonesia sebagai sarana untuk menanggulangi kejahatan, tampaknya tidak menjadi persoalan. Hal ini terlihat dari prakteknya dalam perundang-undangan selama ini yang menunjukkan bahwa penggunaan hukum pidana merupakan bagian dari kebijakan atau politik hukum yang dianut di Indonesia. ${ }^{21}$

Usaha penanggulangan kejahatan dengan hukum pidana pada hakikatnya juga merupakan bagian dari usaha penegakan hukum (khususnya penegakan hukum pidana) karena itu, sering pula dikatakan bahwa politik atau kebijakan huum pidana juga merupakan bagian dari kebijakan penegakan hukum (law enforcement policy). Usaha penanggulangan kejahatan lewat pembuatan undangundang (hukum) pidana merupakan bagian integral dari usaha perlindungan hukum terhadap masyarakat. Sehingga, wajar apabila kebijakan atau politik hukum pidana juga merpakan bagian integral dari kebijakan atau politik sosial (social policy). ${ }^{22}$

Penggunaan upaya hukum pidana merupakan salah satu upaya untuk mengatasi masalah sosial termasuk dalam bidang kebijakan penegakan hukum. Di

\footnotetext{
${ }^{20}$ Barda Nawawi Arief, Bunga Rampai Kebijakan Hukum Pidana, PT. Citra Aditya Bakti, Bandung, 1996, hlm. 28

${ }^{21}$ Sudarto, Kapita Selekta Hukum Pidana, Alumni, Bandung, 1981, hlm. 159

${ }^{22}$ M. Hamdan, Politik Hukum Pidana, PT. Raja Grafindo Persada, Jakarta, 1997, hlm. 24
} 
samping itu, karena tujuannya untuk mencapai kesejahteraan masyarakat pada umumnya, maka kebijakan penegakan hukum inipun termasuk bidang kebijakan sosial, yaitu segala usaha yang rasional untuk mencapai kesejahteraan. Sebagai suatu masalah yang termasuk masalah kebijakan, penggunaan hukum pidana sebenarnya tidak merupakan suatu keharusan. ${ }^{23}$

Dipandang dari sudut yang luas tentang kebijakan hukum pidana pada prinsipya bukanlah semata-mata pekerjaan teknik perundang-undangan yang dapat dilakukan secara yuridis normatif dan ssistemik-dogmatik, tetapi juga memerlukan pendekatan yuridis faktual yang dapat berupa pendekatan sosiologis, psikologis, historis dan komparatif, bahkan memerlukan pula pedekatan integral dengan kebijakan sosial dengan pembangunan nasional pada umumnya. Persoalan politik hukum adalah terletak diantara ius constitutum dengan ius constituendum. $^{24}$

Sebagai bahan perbandingan tentang korban tindak pidana narkotika, di Negara Portugal dekriminalisasi penyalah guna narkotika diatur dalam UU Narkotika Portugal Pasal 2 (1), pembelian, kepemilikan dan penggunaan narkotika untuk kepentingan pribadi selama 10 hari merupakan pelanggaran administrasi, apabila kepemilikannya melebihi batas pemakaian selama 10 hari maka secara hukum pemilik narkotika adalah pengedar. Namun begitu penyalahgunaan narkotika tetap dilarang. Dampak dari dekriminalisasi di Portugal adalah penurunan angka penggunaan narkotika usia produktif, penurunan ketertarikan penggunaan narkotika, peredaran narkotika menurun serta pengidap HIV, hepatitis, kematian yang diakibatkan oleh penggunaan narkotika menurun drastis. $^{25}$

Dekriminalisasi adalah suatu proses dimana suatu perbuatan yang merupakan kejahatan karena dilarang dalam perundang-undangan pidana, kemudian pasal yang menyangkut perbuatan itu dicabut dari perundang-undangan dan dengan demikian perbuatan itu bukan lagi kejahatan. ${ }^{26}$

\footnotetext{
${ }^{23}$ Ibid, hlm. 43

${ }^{24}$ Ibid, hlm. 44

25 Anang Iskandar, Dekriminalisasi Penyalah Guna Narkotika dalam Konstruksi Hukum Positif Di Indonesia, https://bnn.go.id/dekriminalisasi-penyalah-guna-narkotika-dalam-konstruksihukum-positif-di-indonesia/[diakses tanggal 14/01/2022, pukul 15:32]

${ }^{26}$ Ibid
} 
Selain itu juga di Spanyol, undang-undang yang diterapkan, "The Law on Protection of Citizens Security" menyebutkan, seseorang yang mengonsumsi Narkoba di depan umum dianggap sebagai pelanggaran serius dan dikenakan sanksi administratif yang umumnya berupa sanksi denda. Tetapi sanksi tersebut dapat ditangguhkan jika pengguna tersebut bersedia mengikuti program terapi. Selain itu, terdapat celah hukum obat di Spanyol yaitu konsumsi obat publik dilarang, tetapi penggunaan obat secara personal tidak dilarang. Sementara untuk kasus perdagangan, Undang-Undang Narkoba Spanyol menetapkan hukuman yang cukup berat, khususnya penjualan kepada anak-anak di bawah usia 18 tahun, atau dalam jumlah besar melebihi 500 dosis (over 500 doses). ${ }^{27}$

Di Indonesia pola semacam itu belum diterapkan, korban pengguna Narkoba masih dimasukkan ke dalam penjara meskipun selama proses tahanan diperkenankan untuk direhabilitasi namun belum menjadi solusi efektif. Sistem hukum di Indonesia harus mulai melakukan kebijakan dengan langsung membawa korban pengguna Narkoba ke tempat rehabilitasi. Apabila korban pengguna Narkoba ditangkap polisi atau dilaporkan orang tua dan/atau wali maka mereka harus ditempatkan di tempat rehabilitasi. Namun demikian usaha pemerintah Indonesia menuju dekriminalisasi terhadap korban pengguna Narkoba sebenarnya telah dimulai dengan dikeluarkannya SEMA No. 07 Tahun 2009 yang kemudian diganti dengan SEMA No. 4 Tahun 2010 tentang Penempatan Penyalahgunaan, Korban Penyalahgunaan dan Pecandu Narkotika ke Dalam Lembaga Rehabilitasi Medis dan Rehabilitasi Sosial, yang secara substansial kedua SEMA tersebut tidak ada perubahan.

Dengan demikian, model pemidanaan terhadap korban pengguna Narkoba harus berorientasi pada penyembuhan dan pemulihan, baik melalui lembagalembaga medis (rumah sakit dan puskesmas), maupun lembaga sosial. Sehingga melahirkan model berupa penanganan yang dapat diterapkan terhadap korban pengguna Narkoba.

${ }^{27}$ Sujono, A.R, dan Bony Daniel, Komentar dan Pembahasan Undang-Undang Nomor 35 Tahun 2009 tentang Narkotika, Sinar Grafika, Jakarta, 2011, hlm. 23. 


\section{Penutup}

Perlindungan hukum terhadap korban tindak pidana narkotika dalam perspektif Undang-Undang Nomor 35 Tahun 2009 Tentang Narkotika belum diterapkan sehingga menimbulkan ketidakadilan dan ketidakpastian hukum. Adapun bentuk perlindungan hukum yang seharusnya diberikan kepada korban adalah tindakan rehabilitasi dalam bentuk rehabilitasi medis dan rehabiltiasi sosial. Namun yang terjadi di Indonesia, korban tindak pidana narkotika justru dijatuhi pidana penjara. Tidak ada kejelasan di dalam Undang-Undang Nomor 35 Tahun 2009 Tentang Narkotika yang memisahkan antara bandar, pengedar, dan korban. Dengan demikian terjadi peradilan yang sesat.

Kebijakan hukum pidana di masa yang akan datang dalam memberikan perlindungan hukum terhadap korban penyalahguna narkotika selayaknya tidak hanya melakukan pembaharuan terhadap hukum pidana materiil saja, tetapi juga pembaharuan terhadap hukum pidana formil dan hukum pelaksana pidana. Selain itu, model pemidanaan terhadap korban pengguna Narkoba harus berorientasi pada penyembuhan dan pemulihan, baik melalui lembaga-lembaga medis (rumah sakit dan puskesmas), maupun lembaga sosial. Sehingga melahirkan model berupa penanganan yang dapat diterapkan terhadap korban pengguna Narkoba.

\section{Daftar Pustaka}

Bambang Waluyo, Viktimologi Perlindungan Korban dan Saksi, Sinar Grafika, Jakarta, 2018.

Barda Nawawi Arief, Beberapa Aspek Kebijakan Penegakan dan Pengembangan Hukum Pidana, PT. Citra Aditya Bakti, Bandung, 2005.

Barda Nawawi Arief, Bunga Rampai Kebijakan Hukum Pidana, PT. Citra Aditya Bakti, Bandung, 1996.

Hari Sasangka, Narkotika dan Psikotropika Dalam Hukum Pidana Untuk mahasiswa dan Praktisi Serta Penyuluh Narkoba, Mandar Maju, Bandung, 2003.

Lilik Mulyadi, Bunga Rampai Hukum Acara Pidana, PT. Alumni, Bandung, 2012.

M. Hamdan, Politik Hukum Pidana, PT. Raja Grafindo Persada, Jakarta, 1997.

Moh. Makaro Taufik, Suhasril, dan Moh. Zakky, Tindak Pidana Narkotika, Ghalia Indonesia, Bogor, 2005.

Muhammad Yamin, Tindak Pidana Khusus, Pustaka Setia, Bandung, 2012. 
Parasian Simanungkalit, Model Pemidanaan Yang Ideal Bagi Korban Pengguna Narkoba Di Indonesia, Yustisia, Surakarta, 2013.

Siswanto Sunarsono, Penegakan Hukum Psikotropika Dalam Kajian Sosiologi Hukum, Grafindo, Jakarta, 2004.

Soedjono Dirdjosisworo, Narkotika dan Remaja, Alumni, Bandung, 1977.

Soerjono Soekanto and Sri Mamudji, Penelitian Hukum Normatif: Suatu Tinjauan Singkat, Rajagrafindo Perkasa, Jakarta, 2007.

Soetandyo Wignjosoebroto, Hukum: Paradigma, Metode dan Dimanika Masalahnya. Elsamhuma, Jakarta, 2002.

Sudarto, Kapita Selekta Hukum Pidana, Alumni, Bandung, 1981.

Sujono, A.R, dan Bony Daniel, Komentar dan Pembahasan Undang-Undang Nomor 35 Tahun 2009 tentang Narkotika, Sinar Grafika, Jakarta, 2011.

Teguh Prasetyo, Kriminalisasi Dalam Hukum Pidana, Nusa Media, Bandung, 2010.

Yesmil Anwar \& Adang, Pembaharuan Hukum Pidana, PT. Grasindo, Jakarta, 2008.

Anang Iskandar, Dekriminalisasi Penyalah Guna Narkotika dalam Konstruksi Hukum Positif Di Indonesia, https://bnn.go.id/dekriminalisasi-penyalahguna-narkotika-dalam-konstruksi-hukum-positif-di-indonesia/[diakses tanggal 14/01/2022, pukul 15:32] 